\begin{tabular}{|c|l}
\hline CaM/onstruction and Material Journal & Volume 1 No.3 \\
e-ISSN 2655-9625, http://jurnal.pnj.ac.id/index.php/cmi & November 2019 \\
\hline
\end{tabular}

\title{
PEMANFAATAN LIMBAH BOTTOM ASH DAN LIMBAH KACA PADA CAMPURAN BATAKO
}

\author{
Desi Putri ${ }^{1}$, Rr. Mekar Ageng Kinasti ${ }^{2}$, Divad Fredonanta Lalus ${ }^{3}$ \\ 1,2,3 Jurusan Teknik Sipil, Sekolah Tinggi Teknik PLN, Jalan Lingkar Luar Barat Duri Kosambi, \\ Cengkareng, Jakarta Barat, 11750 \\ desi.putri@sttpln.ac.id
}

\begin{abstract}
Increased housing construction has resulted in an increased demand for concrete beams, this of course has an impact on the needs of basic materials such as sand. The increasing demand for sand will have an impact on the price of sand, especially for areas that are difficult to get sand as raw material. An alternative to sand is to use basic ash. This waste will accumulate and pollute the environment. One effort to reduce this waste was to make glass waste as a substitute for cement in bricks. This study aimed at determining the compressive strength of concrete beams using bottom ash and cement with glass waste in a certain percentage. This research was carried out in two testing stages. In the initial stage of the study, the preliminary phase carried out included the physical properties of the material testing. The second step was to make test specimens with four variations of the mixture, that was $0 \%, 10 \% \mathrm{LK}+10 \% \mathrm{BA}, 10 \% \mathrm{LK}+20 \% \mathrm{BA}$ dan $10 \% \mathrm{LK}+30 \% \mathrm{BA}$, and then a compression test on 7, 14 and 28 days of age. From the test results, the compressive strength results obtained from the brick using bottom ash and glass waste were respectively 4,13 MPa, 4,31 MPa, 7,14 MPa dan 5,21 Mpa. Based on the results of the research (no subject of the sentence) we concluded that the most increased compressive strength of the brick was on $10 \% \mathrm{LK}+20 \% \mathrm{BA}$ variation, and the decrease of compressive strength started on $10 \% \mathrm{LK}+30 \% \mathrm{BA}$ variation.
\end{abstract}

Keywords : brick, residential, bottom ash, compressive strength, glass waste.

\begin{abstract}
ABSTRAK
Meningkatnya pembangunan hunian mengakibatkan naiknya permintaan akan batako, hal ini tentunya berdampak terhadap kebutuhan bahan dasar batako seperti pasir juga mengalami peningkatan. Kebutuhan pasir yang meningkat akan menaikkan harga pasir, terutama untuk daerah yang sulit mendapatkan bahan baku pasir. Bahan alternatif pengganti bahan baku pasir salah satunya adalah dengan memanfaatkan limbah bottom ash. Selama ini limbah bottom ash hanya ditimbun di lahan kosong, sehingga menumpuk. Hal ini tentunya sangat berbahaya apabila bottom ash terbawa angin atau air karena dapat mencemari lingkungan serta mengganggu pernapasan. Limbah kaca merupakan salah satu limbah anorganik hingga saat ini. Limbah ini dibuang begitu saja tanpa adanya pengolahan yang lebih bermanfaat sehingga menumpuk dan terkesan hanya mengotori lingkungan sekitarnya. Salah satu upaya mengurangi limbah ini dengan menjadikan limbah kaca sebagai substitusi semen pada batako. Penelitian ini bertujuan untuk mengetahui kekuatan tekan batako bila pasirnya digantikan dengan limbah bottom ash dan semen digantikan dengan limbah kaca menggunakan prosentase tertentu. Penelitian dilakukan secara eksperimental di laboratorium dengan dua tahap pengujian. Pada tahap awal penelitian dilakukan pengujian pendahuluan meliputi pengujian sifat fisik bahan. Tahap kedua dilakukan pembuatan benda uji dengan dengan empat variasi campuran yaitu 0\%, $10 \% \mathrm{LK}+10 \% \mathrm{BA}, 10 \% \mathrm{LK}+20 \% \mathrm{BA}$ dan $10 \% \mathrm{LK}+30 \% \mathrm{BA}$ kemudian dilakukan uji tekan pada umur 7, 14 dan 28 hari. Dari hasil pengujian, didapat hasil kuat tekan batako menggunakan limbah bottom ash dan limbah kaca masing-masing adalah 4,13 MPa, 4,31 MPa, 7,14 MPa dan 5,21 MPa. Berdasarkan hasil penelitian dapat disimpulkan bahwa kenaikan kuat tekan terbesar batako terdapat pada variasi $10 \% \mathrm{LK}+20 \% \mathrm{BA}$ dan terjadi penurunan kuat tekan batako pada variasi $10 \% \mathrm{LK}+30 \% \mathrm{BA}$.
\end{abstract}

Kata kunci : Batako, hunian, bottom ash, kuat tekan, limbah kaca. 


\section{PENDAHULUAN}

Batako merupakan salah satu bagian material yang biasa digunakan sebagai dinding dalam sebuah konstruksi. Semakin banyaknya pembangunan rumah dan konstruksi gedung mengakibatkan naik pula pemesanan akan batako. Batu bata yang awalnya sering digunakan, lambat laun tergeser dengan penggunaan batako yang lebih mudah didapat dan dibuat. Proses pembuatan batako tidak perlu mengalami pembakaran seperti halnya pada batu bata. Ukuran batako yang lebih besar dari pada batu bata akan memudahkan dalam pengerjaan dinding sehingga lebih cepat selesai dan cukup kuat untuk semua penggunaan yang biasa menggunakan batu bata, membuat para pengguna batu bata beralih ke batako. Oleh karena itu, secara tidak langsung berdampak pada peningkatan kebutuhan batako di pasaran, sehingga kebutuhan material seperti semen dan pasir akan sangat meningkat.

Kebutuhan semen dan pasir yang meningkat akan menaikkan harga semen dan pasir, terutama untuk daerah yang sulit mendapatkan semen dan pasir. Inovasi terbaru yang sedang dikembangkan saat ini adalah dengan memanfaatkan limbah kaca sebagai bahan alternatif pengganti semen dan limbah bottom ash sebagai bahan alternatif pengganti pasir.

Limbah kaca merupakan salah satu limbah anorganik. Limbah ini berasal dari limbah sampah rumah tangga, restoran dan kafe. Salah satu upaya untuk memanfaatkan limbah tersebut adalah sebagai bahan substitusi pada campuran batako. Pemilihan limbah kaca dikarenakan bahan baku alternatif ini termasuk mudah diperoleh. Bubuk kaca/serbuk kaca mempunyai sifat pozzoland sehingga dapat berfungsi sebagai pengganti semen dan filler [1][2].

Bottom ash adalah limbah hasil pembakaran batubara yang berasal dari industri maupun pembangkit. Limbah ini akan terus bertambah selama proses produksi. Limbah ini biasanya di timbun di lahan kosong sehingga menumpuk dan sangat berbahaya bila terbawa angin atau air karena dapat mengganggu pernapasan. Berdasarkan hal tersebut maka diperlukan alternatif dalam pengolahan limbah bottom ash tersebut. Bottom ash memiliki ukuran partikel yang berbeda-beda dan lebih mendekati ukuran pasir sehingga bisa dijadikan sebagai bahan pengganti pasir [3].

Melihat kelebihan dari limbah serbuk kaca dan limbah bottom ash yang belum maksimal digunakan, maka perlu diusahakan untuk memanfaatkannya, khususnya sebagai bahan pengganti pasir dan semen dalam pembuatan batako. Berdasarkan hal tersebut, maka perlu adanya penelitian tentang pemanfaatan limbah serbuk kaca sebagai bahan substitusi semen dan limbah bottom ash sebagai bahan subtitusi pasir dalam pembuatan batako.

\section{Limbah Kaca}

Kaca adalah salah satu produk industri kimia yang merupakan gabungan dari berbagai oksida anorganik yang tidak mudah menguap, yang dihasilkan dari dekomposisi dan peleburan senyawa alkali dan alkali tanah, pasir serta berbagai penyusun lainnya [2]. Gagasan awal berpedoman pada pemikiran bahwa unsur unsur kimia yang ada pada kaca sebagian diantaranya sama seperti yang ada pada semen, sehingga apabila 
kaca dihancurkan menjadi serbuk berkemungkinan berfungsi sebagai filler karena persentase kandungan silika (Si02), $\mathrm{Na} 2 \mathrm{O}$ dan $\mathrm{CaO}$ pada kaca yang cukup besar yaitu lebih dari 70\% [4]. Beberapa sifat-sifat kaca secara umum adalah:

- Padatan amorf (short range order);

- Berwujud padat tapi susunan atomatomnya seperti pada zat cair;

- Tidak memiliki titik lebur yang pasti ada range tertentu;

- Transparan, tahan terhadap serangan kimia, kecuali hidrogen fluorida.

Karena itulah kaca banyak dipakai untuk peralatan laboratorium;

- Efektif sebagai isolator;

- Mampu menahan vakum tetapi rapuh terhadap benturan [1]

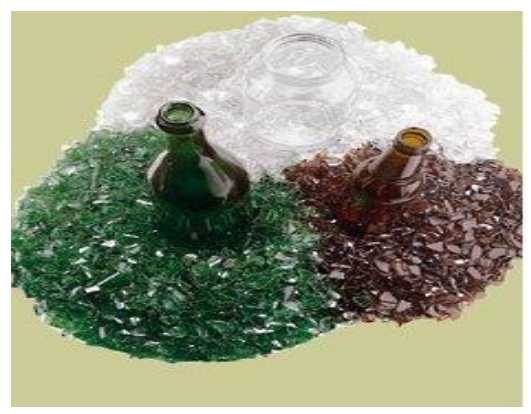

Gambar 1. Limbah kaca

\section{Limbah Bottom Ash}

Bottom ash merupakan material yang tidak terbakar dengan sempurna dari pembakaran suatu material, seperti pada pembakaran batubara. Bottom ash ini diperoleh setelah pembakaran selesai. Biasanya bottom ash menempel pada bagian bawah atau dinding dari tungku pembakaran tersebut. Dengan kata lain bottom ash adalah limbah dari proses pembakaran batubara pada pembangkit dan mempunyai ukuran partikel lebih besar serta lebih berat dari fly ash, sehingga memungkinkan bottom ash dapat jatuh ke dasar tungku pembakaran (boiler).
Bottom ash dapat digunakan sebagai bahan pengganti semen karena mempunyai salah satu unsur kimia semen yang penting pada proses pengikatan yaitu silika. Porsentase bottom ash dapat dimanfaatkan berkisar antara 5\%-55\% dari berat total semen [5]. Berdasarkan komposisi yang terkandung dalam bottom ash maka ada beberapa kemungkinan kegunaan dari bottom ash antara lain:

o Sebagai filler atau pengisi pada campuran aspal dan beton.

o Sebagai lapisan base dan sub base pada perkerasan jalan.

- Sebagai bahan filtrasi.

- Sebagai agregat dalam semen dan beton ringan.

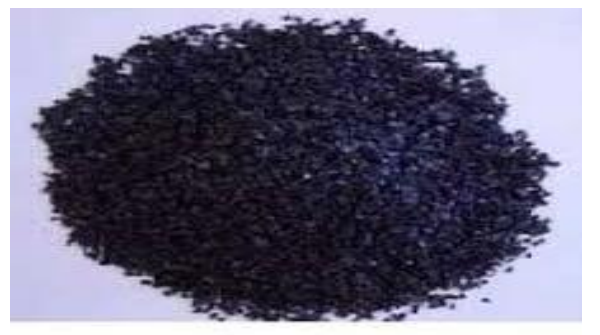

Gambar 2. Limbah bottom ash

\section{KAJIAN PUSTAKA}

Penelitian yang dilakukan oleh Hendra Purnomo, Dkk [6] tentang Pemanfaatan serbuk kaca sebagai substitusi parsial semen pada campuran beton ditinjau dari kekuatan tekan dan kekuatan tarik belah beton, dengan variasi substitusi $0 \%, 2,5 \%, 5 \%, 7,5 \%, 10 \%, 12,5 \%$, dan $15 \%$ Berdasarkan penelitian diperoleh nilai kuat tekan optimum terdapat pada variasi $10 \%$ yaitu sebesar 21,41 Mpa. Sedangkan nilai kuat tarik belah optimum terdapat juga pada variasi $10 \%$ yaitu sebesar 2,78 Mpa.

Penelitian yang dilakukan oleh Mochammad Qomaruddin, dkk [7] tentang Pemanfaatan limbah bottom ash pengganti agregat halus dengan tambahan kapur pada pembuatan paving 
dengan variasi bottom ash 10\%, 20\%, $30 \%$, dan $40 \%$. Diperoleh kuat tekan terbesar terdapat pada variasi $20 \%$, dengan nilai sebesar $156,429 \mathrm{Kg} / \mathrm{cm}^{2}$. (mutu C).

\section{METODE PENELITIAN}

Penelitian dilakukan secara eksperimental di laboratorium Beton Sekolah Tinggi Teknologi PLN. Secara garis besar penelitian terdiri dari dua tahap. Tahap pertama adalah pengujian pendahuluan (pengujian material). Tahap kedua pembuatan benda uji kemudian dilakukan pengujian tekan pada umur 7, 14 dan 28 hari. Agar diperoleh hasil yang optimal diperlukan suatu perencanaan pelaksanaan yang sistematis mulai dari awal sampai selesai dan sesuai dengan tujuan penelitian. Secara garis besar tahap penelitian yang akan dilakukan antara lain :

\section{Tahan Persiapan}

Tahap persiapan berupa pengadaan bahan-bahan yang diperlukan dalam pelaksanaan penelitian. Bahan-bahan tersebut berupa agregat halus (pasir), semen, limbah kaca, limbah bottom ash dan air. Disamping juga mempersiapkan alat-alat yang digunakan dalam penelitian.

2. Pengujian Pendahuluan

Pengujian pendahuluan dilakukan untuk mendapatkan sifat-sifat bahan. Pengujian semen meliputi berat jenis. Pengujian agregat halus meliputi analisa gradasi agregat, berat satuan, dan kadar lumpur. Pengujian limbah kaca meliputi berat jenis, penelitian limbah bottom ash meliputi gradasi dan berat satuan. Selanjutnya dilakukan pembuatan campuran adukan beton (mix design) sesuai dengan variasi komposisi limbah kaca terhadap semen dan limbah bottom ash terhadap agregat halus pada campuran batako.

\section{Pembuatan Benda Uji}

Pembuatan benda uji dengan variasi campuran limbah kaca $10 \%$ dari berat semen dan campuran limbah bottom ash 0\%, 10\%, 20\% dan 30\% dari berat pasir. Benda uji disiapkan masing-masing 3 buah untuk pengujian kuat tekan.

4. Pengujian Kuat Tekan Benda Uji

Untuk pengujian kuat tekan dilakukan pada umur 7 hari, 14 hari dan 28 hari.

5. Analisis Hasil dan Pembahasan

Setelah didapatkan data hasil pengujian kemudian dilakukan analisa dan pembahasan serta membandingkan sifat kuat tekan dari setiap data tersebut.

6. Kesimpulan

Kesimpulan dibuat berdasarkan hasil analisis data penelitian.

\section{Bahan Penelitian}

Bahan yang digunakan dalam penelitian ini adalah :

1. Semen yang dipakai merupakan semen Portland Tipe I merek Gresik.

2. Agregat halus (pasir) diambil dari kepulauan Bangka.

3. Limbah kaca berasal dari pecahan botol yang berada di Jakarta Barat.

4. Limbah bottom ash berasal dari PLTU Suralaya, Cilegon-Banten.

5. Air yang digunakan adalah air tanah di Laboratorium Beton Sekolah Tinggi Teknik PLN. 


\section{Peralatan Penelitian}

Alat yang digunakan untuk penelitian ini adalah sebagai berikut :

a. Timbangan untuk menimbang berat benda uji. Timbangan yang digunakan dengan merek Ohauss GT-2100 dengan ketelitian 0,001 gram.

b. Oven untuk mengeringkan kadar air pasir. Alat yang digunakan dengan merek Memmert Gmbh, D-8540 Schwabach/Western Germany.

c. Satu set alat ayakan yang digunakan untuk mengetahui gradasi pasir dan abu sisa pembakaran sampah.

d. Bejana baja (berat bejana $=4740$ gr, $\mathrm{h}=23 \mathrm{~cm}, \mathrm{r}=12 \mathrm{~cm}, \mathrm{t}-0,5 \mathrm{~cm}$ ) untuk pengujian berat satuan angregat halus.

e. Kerucut terpancung konus, dengan diameter bagian atas $40 \mathrm{~mm}$, diameter bagian bawah $90 \mathrm{~mm}$, dan tinggi $75 \mathrm{~mm}$

f. Picnometer kapasitas $500 \mathrm{ml}$.

g. Mesin uji tekan merk wykehan farrance kapasitas $2000 \mathrm{kN}$.

\section{Tahap Pelaksanaan}

\section{Benda Uji}

Untuk mengetahui kuat tekan batako dilakukan pemodelan eksperimental benda uji dengan komposisi variasi campuran limbah kaca $10 \%$ dari berat semen dan campuran limbah bottom ash $0 \%, 10 \%, 20 \%$ dan $30 \%$ dari berat pasir. Ukuran spesimen untuk keperluan pengujian dengan bentuk spesimen seperti terlihat pada Gambar 3. Jumlah benda uji dan variasinya dijabarkan dalam Tabel 1.

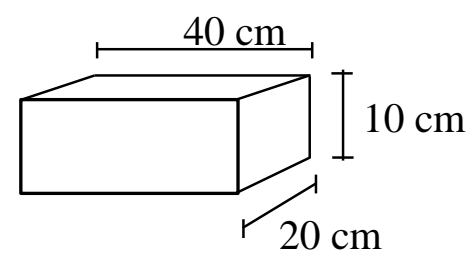

Gambar 3. Bentuk benda uji

\section{Perawatan Benda Uji}

Setelah benda uji dibuat kemudian dilakukan perawatan terhadap benda uji dengan tujuan agar retak-retak pada permukaan batako dapat dihindari serta mutu yang yang diinginkan dapat tercapai.

Tabel 1. Jumlah Benda Uji Semua Variasi

\begin{tabular}{|c|c|c|}
\hline No & Variasi & Jumlah Benda Uji \\
\hline 1 & $\begin{array}{c}0 \% \\
\text { (Normal) }\end{array}$ & $\begin{array}{l}7 \text { Hari (3 Benda Uji) } \\
14 \text { Hari (3 Benda Uji) } \\
28 \text { Hari (3 Benda Uji) }\end{array}$ \\
\hline 2 & $\begin{array}{c}(10 \% \mathrm{LK}+ \\
10 \% \mathrm{BA})\end{array}$ & $\begin{array}{l}7 \text { Hari (3 Benda Uji) } \\
14 \text { Hari (3 Benda Uji) } \\
28 \text { Hari (3 Benda Uji) }\end{array}$ \\
\hline 3 & $\begin{array}{c}(20 \% \mathrm{LK}+ \\
10 \mathrm{BA})\end{array}$ & $\begin{array}{l}7 \text { Hari (3 Benda Uji) } \\
14 \text { Hari (3 Benda Uji) } \\
28 \text { Hari (3 Benda Uji) }\end{array}$ \\
\hline 4 & $\begin{array}{c}(30 \% \mathrm{LK}+ \\
10 \% \mathrm{BA})\end{array}$ & $\begin{array}{l}7 \text { Hari (3 Benda Uji) } \\
14 \text { Hari (3 Benda Uji) } \\
28 \text { Hari (3 Benda Uji) }\end{array}$ \\
\hline & Total & 36 Benda Uji \\
\hline
\end{tabular}

\section{Pelaksanaan Pengujian dan Pengumpulan Data}

Tahap ini merupakan tahap melakukan pengujian tiap benda uji yang sudah dibuat untuk uji kuat tekan yang kemudian dicatat hasilnya.

\section{Tahap Analisa dan Pembahasan}

Setelah didapatkan data hasil pengujian kemudian dilakukan analisa dan pembahasan serta membandingkan sifat kuat tekan dari setiap data tersebut.

\section{HASIL dan PEMBAHASAN}

Hasil pengujian pendahuluan pada material pembentuk campuran batako diperlukan dalam rancangan batako. Pengujian pendahuluan tersebut diantaranya berat jenis semen, gradasi pasir, modulus halus butir pasir, berat 
satuan pasir, kadar lumpur pasir, gradasi limbah bottom ash, modulus halus butir bottom ash dan berat jenis limbah kaca . Hasil pengujian pendahuluan material disajikan pada Tabel 2.

Tabel 2. Hasil Uji Material

\begin{tabular}{lc}
\hline \multicolumn{1}{c}{ Pengujian } & Hasil \\
\hline Berat Jenis Semen & $3,15 \mathrm{gr} / \mathrm{cm}^{3}$ \\
Gradasi Pasir & Zona IV \\
Modulus Halus Butir Pasir & 1,85 \\
Berat Satuan Pasir & $1414,03 \mathrm{~kg} / \mathrm{m}^{3}$ \\
Kadar Lumpur Pasir & $1,482 \%$ \\
Modulus Halus Butir bottom & 3,25 \\
ash & Zona III \\
Gradasi bottom ash & (pasir kasar) \\
\hline
\end{tabular}

Pengujian kuat tekan dilakukan setelah benda uji berumur 7 hari, 14 hari dan 28 hari. Berdasarkan hasil pengujian kuat tekan yang telah dilaksanakan dengan variasi persentase limbah kaca sebagai pengganti semen dan limbah bottom ash sebagai pengganti pasir dengan variasi adalah $0 \%, 10 \% \mathrm{LK}+10 \% \mathrm{BA}, 10 \%$ $\mathrm{LK}+20 \%$ BA dan $10 \% \mathrm{LK}+30 \%$ BA didapatkan nilai kuat tekan paving block sebagai berikut :

Tabel 3. Hasil Uji Tekan Semua Variasi

\begin{tabular}{ccccc}
$\begin{array}{c}\text { Variasi } \\
\text { Campuran }\end{array}$ & $\begin{array}{c}\text { Hari } \\
\text { Ke }-\end{array}$ & $\begin{array}{c}\text { Kuat tekan } \\
\left(\mathbf{K g} / \mathbf{c m}^{2}\right)\end{array}$ & $\begin{array}{c}\text { Kuat tekan } \\
(\mathbf{M P a})\end{array}$ & Mutu \\
\hline 0\% & 7 & 19,35 & 1,93 & - \\
$($ Normal) & 14 & 32,17 & 3,22 & - \\
& 28 & 41,35 & 4,13 & IV \\
Variasi 1 & 7 & 22,45 & 2,24 & - \\
$(10 \%$ & 14 & 36,13 & 3,61 & IV \\
SK+10\% & 28 & 43,15 & 4,31 & IV \\
BA) & 7 & 25,23 & 2,52 & - \\
Variasi 2 & 14 & 40,56 & 4,05 & IV \\
$(10 \%$ & 28 & 71,34 & 7,13 & II \\
SK+20\% & 7 & 24,15 & 2,41 & IV \\
BA) & 14 & 37,43 & 3,743 & IV \\
Variasi 3 & 28 & 52,13 & 5,21 & III \\
$(10 \%$ & & & &
\end{tabular}

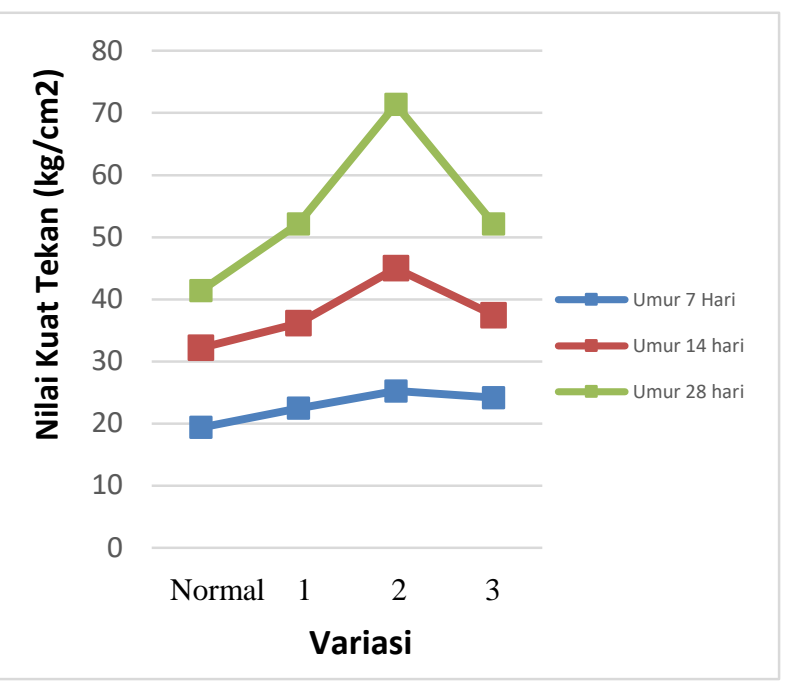

Gambar 4. Grafik hasil pengujian kuat tekan semua variasi

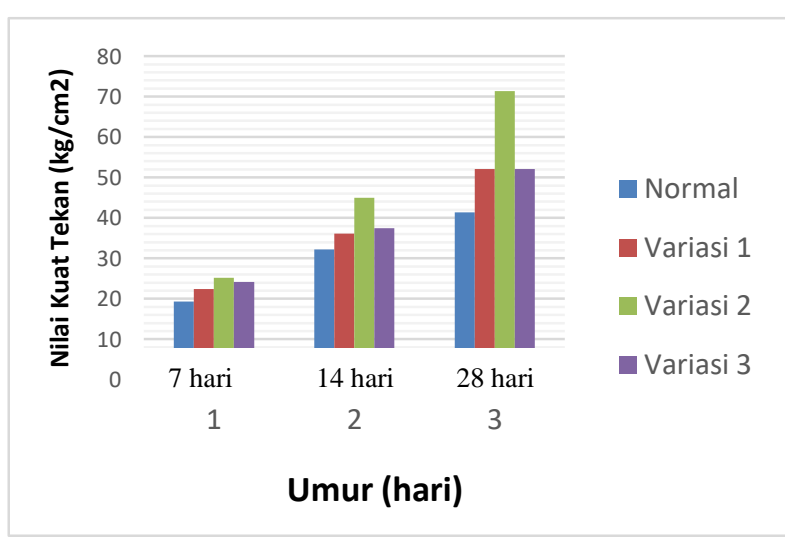

Gambar 5. Barchart hasil pengujian kuat tekan semua variasi

Berdasarkan pengujian kuat tekan batako yang dilakukan, diketahui kuat tekan optimum yang dihasilkan terdapat pada batako dengan variasi (serbuk kaca $10 \%+$ bottom ash 20\%), pada umur 28 hari, yaitu sebesar 7,13 MPa dan kuat tekan terendah terdapat pada variasi $0 \%$ (normal), pada umur 28 hari, yaitu sebesar 4,13 MPa.

\section{KESIMPULAN}

Berdasarkan penelitian yang dilakukan, maka dapat disimpulkan bahwa, limbah 
bottom ash dan limbah serbuk kaca dapat dimanfaatkan sebagai bahan tambah pada pembuatan batako, sehingga pemanfaatan ini dapat pula dijadikan sebagai alternatif bahan konstruksi yang ramah lingkungan.

Berdasarkan penelitian yang dilakukan, nilai kuat tekan optimum terdapat pada variasi (10 SK + $20 \mathrm{BA})$, pada umur 28 hari, yaitu sebesar 7,13 $\mathrm{MPa}$, dan termasuk dalam kategori batako mutu II, berdasarkan SNI 03 - 049 - 1989 [8] tentang syarat mutu rata - rata batako. Sedangkan nilai kuat tekan terendah terdapat pada variasi $0 \%$ (normal), pada umur 28 hari, yaitu sebesar 4,13 $\mathrm{MPa}$ dan termasuk dalam kategori batako mutu IV berdasarkan SNI 03 - 049 1989 [8] tentang syarat mutu rata - rata batako.

\section{DAFTAR PUSTAKA}

[1] Dian Sudianto, 2011. Jenis Kaca dan Aplikasinya. Kompasiana Beyond blogging.

[2] Wibowo, Levin. 2013. Pengaruh Penambahan Serbuk Kaca dan Water Reducing High Range Admixtures terhadap Kuat Desak dan Modulus Elastisitas pada Beton, Tugas Akhir Program Studi Teknik Sipil Universitas Atma Jaya Yogyakarta. Yogyakarta: UAJY.

[3] Muhardi, 2016, Karakteristik Abu Terbang dan Abu Dasar dalam Geoteknik. Jurnal Aptek Vol 8. No. 2.

[4] Karwur, Handy Yohanes., Dkk. 2013. Kuat Tekan Beton Dengan Bahan Tambah Serbuk Kaca Sebagai Substitusi Parsial Semen. Jurnal Sipil Statik Vol. 1, 276281.

[5] Ali, N., Karimah R., \& Meiyanto, M.E (2014). Pengaruh Bottom Ash sebagai Pengganti Pasir dan Limbah Karbit sebagai Bahan Tambah Semen terhadap Berat Jenis, Kuat
Tekan dan Absorbsi Batako, ejuornal umm. ac.id, Volume 12 nomor 1 .

[6] Hendra Purnomo, dkk, 2014. Pemanfaatan Serbuk Kaca Sebagai Substitusi Parsial Semen Pada Campuran Beton Ditinjau Dari Kekuatan Tekan Dan Kekuatan Tarik Belah Beton. Jurnal Forum Propesional Teknik Sipil

[7] Mochammad Qomarudin, dkk (2017). Pemanfaatan Limbah Bottom Ash Pengganti Agregat Halus dengan Tambahan Kapur Pada Pembuatan Paving Block. Jurnal Reviews In Civil Engineering, Vol 1 No. 1.

[8] Badan Standarisasi Nasional, 1989, SNI- 03-0349-1989, Bata Beton Untuk Pasangan Dinding, Jakarta. 
Desi Putri, dkk, Pemanfaat Limbah Bottom Ash 